
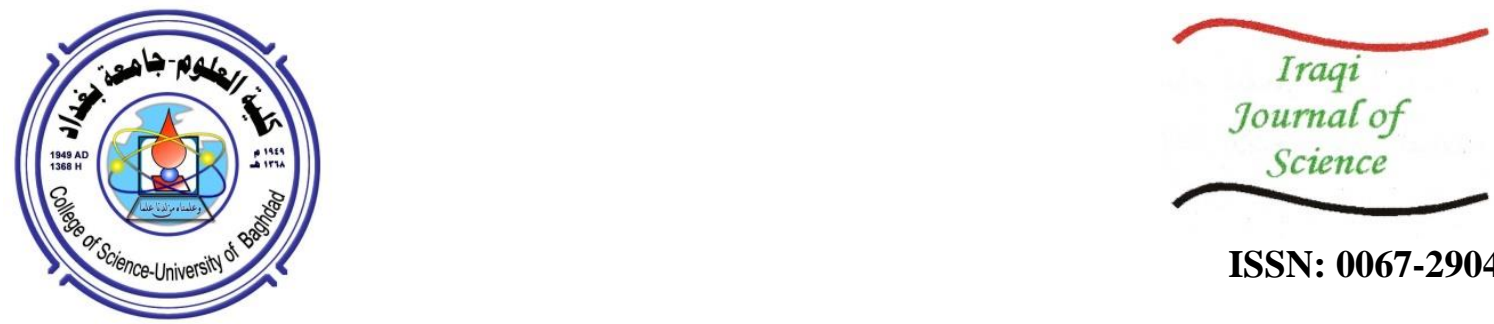

ISSN: 0067-2904

\title{
Complete Classification of Degree 7 for Genus 1
}

\author{
Peshawa M. Khudhur \\ Department of Mathematics, Faculty of Scinence, Soran University, Kurdistan Region, Iraq \\ Department of Petroleum and Mining Engineering, Petroleum and Mining Engineering, Tishk International \\ University, Kurdistan Region, Iraq
}

Received: 9/3/2020

Accepted: 9/5/2020

\begin{abstract}
Assume that $\mathcal{F}: \mathrm{X} \rightarrow \mathbb{P}$ is a meromorphic fuction of degree $\mathrm{n}$ where $\mathrm{X}$ is compact Riemann surface of genus $\mathrm{g}$. The meromorphic function gives a branched cover of the compact Riemann surface X. Classes of such covers are in one to one correspondence with conjugacy classes of $r$-tuples $\left(\alpha_{1}, \alpha_{2}, \ldots, \alpha_{r}\right)$ of permutations in the symmetric group $\mathrm{S}_{\mathrm{n}}$, in which $\alpha_{1} \cdot \alpha_{2} \ldots \ldots \alpha_{\mathrm{r}}=1$ and $\alpha_{\mathrm{i}}^{\prime} \mathrm{s}$ generate a transitive subgroup $\mathrm{G}$ of $\mathrm{S}_{\mathrm{n}}$. This work is a contribution to the classification of all primitive groups of degree 7, where $\mathrm{X}$ is of genus one.
\end{abstract}

Keywords: Monodromy Groups, Genus one Systems and Primitive Groups.

\section{INTRODUCTION}

A function $\mathcal{F}: X \rightarrow \mathbb{P}$ is a non-constant meromorphic function from compact connected Riemann surface $X$ of genus $g$ to Riemann sphere $\mathbb{P}$, if it can locally be described as two holomorphic functions. Furthermore, the mesomorphic function $\mathcal{F}$ is of degree $n$ if the order of the fiber $\left(\left|\mathcal{F}^{-1}(x)\right|\right)$ for general $x$ equal to $n$. A point $\rho$ in $\mathbb{P}$ is a branch point if $\left(\left|\mathcal{F}^{-1}(\rho)\right|<n\right.$. We suppose that $Y=\left\{\rho_{1}, \rho_{2}, \ldots \rho_{r}\right\}$ is the branch points of the meromorphic function $\mathcal{F}$. The fundamental group $\pi_{1}(\mathbb{P} \backslash Y, x)$ for any $x \in \mathbb{P} \backslash Y$ acts transitively on $\mathrm{n}$ elements of the fiber. This action gives us a homomorphism $\mu_{F}: \pi_{1}(\mathbb{P} \backslash Y, x) \rightarrow S_{n}$. The image of $\mu_{F}$ is called Monodromy group of $\mathcal{F}$ and denoted by $\operatorname{Mon}(\mathrm{X}, \mathcal{F})$. We denote $\beta_{i}$ for $1 \leq i \leq r$ as the closed path winding once around the point $\rho_{i}$. So, the fundamental group $\pi_{1}(\mathbb{P} \backslash Y, x)$ is generated by the homotopy class of $\beta_{i}$. This generator satisfies the relation $\beta_{1} . \beta_{2}, \ldots . \beta_{r}=1$, which yields the generators $\left\{\alpha_{1}, \alpha_{2}, \ldots, \alpha_{r}\right\}$ of monodromy group $\operatorname{Mon}(\mathrm{X}, \mathcal{F})$, where $\alpha_{i}=\mu_{F}\left(\beta_{i}\right)$ satisfies the following conditions

$$
\begin{aligned}
& G=\left\langle\alpha_{1}, \alpha_{2}, \ldots, \alpha_{r}\right\rangle \\
& \alpha_{1} \cdot \alpha_{2}, \ldots . \alpha_{r}=1 \\
& \sum_{i=1}^{r}{ }_{i n d} \alpha_{i}=2(n+g-1)
\end{aligned}
$$

Equation 3 is called Riemann Hurwtiz formula where ind $\alpha_{i}=n-\operatorname{Number}$ of $\operatorname{orbit}\left(\alpha_{i}\right)$ on $\mathcal{F}^{-1}\left(\rho_{i}\right)$. Let $\mathrm{G}$ be a transitive subgroup of $S_{n}$. A genus g-system is a tuple $\left(\alpha_{1}, \cdots, \alpha_{r}\right)$ satisfying equations (1), (2) and (3) [1]. A natural question that arises from this study is: what value can monodromy group $\operatorname{Mon}(\mathrm{X}, \mathcal{F})$ take for a fixed genus of $\mathrm{X}$ ?

Guralnick and Thompson [2], in 1990, gave a conjecture; There is a finite set $\varsigma(g)$ of simple groups, for any positive integer $\mathrm{g}$, such that if $\mathcal{F}: X \rightarrow \mathbb{P}$ is a cover, where $X$ is compact connected Riemann surface of genus $g$ and $\mathfrak{J}$ is a non-commutative composition factor of $\operatorname{Mon}(X, \mathcal{F})$, then this composition factor is either an isomorphism to the finite set $\varsigma(g)$ or $\mathfrak{I}$ is 
equal to $A_{n}$. This fact was established in 2001 by Frohardt and Magaard [1]. As the set $\varsigma(g)$ is finite, one hopes to see the sets $\varsigma(0), \varsigma(1)$ and $\varsigma(2)$ clearly. In 1990, Guralnick and Thompson[2] used Riemann's Existence theorem to prove that the finite set $\varsigma(g)$ takes place in a primitively monodromy action. That is, if $\mathrm{G}$ is a group in the set $\varsigma(g)$, then there exists $(\mathrm{X}, \mathcal{F})$ in which $\mathrm{G}=\operatorname{Mon}(\mathrm{X}, \mathcal{F})$, and this group acts primitively on the fibers. This result refers to the theorem of Aschbacher and Scott [3].

Theorem1:( Aschbacher and Scott). Let $G$ be a finite group, $F(G)$ be a generated fitting subgroup of the group $\mathrm{G}$, and $\mathrm{L}$ be a maximal subgroup of $\mathrm{G}$ such that $\cap_{g \in G} L^{g}=\{1\}$. Let $\mathrm{K}$ be a minimal normal subgroups of $\mathrm{G}$ and $\mathrm{P}$ be a minimal normal subgroup of $\mathrm{K}$. Let $\nabla=\left\{P_{1}, \ldots, P_{t}\right\}$ be the set of $G$ conjugates of $P$. Then $G=L K$ and exactly one of the following holds:

1 - $\mathrm{P}$ has prime order.

2- $\mathrm{F}(\mathrm{G})=\mathrm{K} \times B$ where $K \cong B$ and $L \cap K=1$.

3- $\mathrm{F}(\mathrm{G})=\mathrm{K}$ is non-commutative and $L \cap K=1$.

4- $\mathrm{F}(\mathrm{G})=\mathrm{K}$ is non-commutative and $L \cap K \neq L \cap P=\{1\}$.

5- $\mathrm{F}(\mathrm{G})=\mathrm{K}$ and $L \cap K=L \cap P_{1} \times \ldots \times P_{t}$ where $P_{i}=L \cap P \neq\{1\}$.

The first case in the above theorem was studied by Guralnick and Thompson [2]. They showed that there are only finitely many primitive affine groups which occur as a composition factor of a primitive genus zero. Furthermore, MohammedSalih [4] studied the same case of genus one and two. Cases 2 and 3 of the above theorem were considered by Shilh [5] and Guralnick and Thompson [2], respectively. They showed that there is no primitive genus zero system. Case 4 of theorem 1 was investigated by Aschbacher [6], who proved that the general fitting subgroup $(\mathrm{F}(\mathrm{G}))$ in case of genus zero system must be equal to $A_{5} \times A_{5}$. MohammedSalih [7] classified the primitive group $A_{8}$ for genus zero. The final case was studied by Khudhur $[8,9,10]$, who determined all sporadic simple groups of genus zero, one, and two. Our aim in this paper is to determine all primitive genus one groups of degree seven, except $S_{7}$. Now we give the following theorem.

Theorem 2: Let $\mathrm{G}$ denotes a group of degree 7. There exists non-constant meromorphic function $\mathcal{F}$ from compact connected Riemann surface $X$ of genus one, such that $\mathrm{G}$ is a composition factor of $\operatorname{Mon}(X, \mathcal{F})$, if and only if $G \cong 7: 3, A G L(1,7), L(3,2)$ and $A_{7}$. Next, we will prove theorem 2 .

\section{2- PRELIMINARY}

In this section, we provide some backgrounds and results, while more are presented in, Haval , 2014, Peshawa,2016 and Volkein He.1996. From now onwards, we denote the space of cardinality $r$ of subsets $\mathbb{C}$ by $O_{r}$.

Definition 2.1 [4,5]. Let $B \in O_{r}$ and $x \in \mathbb{P} \backslash Y$. We call a map $\mathcal{F}: \pi_{1}(\mathbb{P} \backslash Y, x) \rightarrow G$ as admissible if it is a surjective homomorphism, and $\mathcal{F}\left(\sum_{b}\right) \neq 1$ for each $b \in B$. Here $\sum_{b}$, is the conjugacy class of $\pi_{1}(\mathbb{P} \backslash Y, x)$.

Definition 2.2 [4,5]. Let $B \in O_{r}$ and $\mathcal{F}: \pi_{1}(\mathbb{P} \backslash Y, x) \rightarrow G$ is admissible. Then, we say that the two pairs $(B, \mathcal{F})$ and $\left(B^{*}, \mathcal{F}^{*}\right)$ are A -equivalent if and only if $\mathcal{F}=\mathcal{F}^{*}$ and $\mathcal{F}^{*}=a \circ \mathcal{F}$ for some $a \in A$.

Let $[B, \mathcal{F}]_{A}$ denote the $A$-equivalence class of $(B, \mathcal{F})$. The set of equivalence classes $[B, \mathcal{F}]_{A}$ is denoted by $H_{r}^{A}(G)$ and is called the Hurwitz space of $G$-covers.

We now introduce the Nielsen classes as follows. For a ramification type $C=\left\{C_{1}, \ldots, C_{r}\right\}$, $N(C)=\left\{\left(x_{1}, x_{2}, \ldots, x_{r}\right): G=\left\langle x_{1}, x_{2}, \ldots, x_{r}\right\rangle, \prod_{i}^{r} x_{i}=1, \exists \sigma \in S_{n}\right.$ such that $x_{i} \in C_{i \sigma}$ for all $\left.i\right\}$.

Lemma 2.3 [5]. The map $\psi_{A}: H_{r}^{A}(G) \rightarrow O_{r}, \psi_{A}([P, \mathcal{F}])=P$ is a covering.

Lemma2.4 [5]. We obtain a bijection $\psi_{A}^{-1}\left(P_{0}\right) \rightarrow \epsilon_{r}^{A}(G)$ by sending $\left[P_{0}, \mathcal{F}\right]_{A}$ to the generators $\left(x_{1}, x_{2}, \ldots, x_{r}\right)$ where $x_{i}=\mathcal{F}\left(\left[\gamma_{i}\right]\right)$ for $i=1, \ldots, r$.

The group $A$ also acts on $N(C)$ via sending $\left(x_{1}, x_{2}, \ldots, x_{r}\right)$ to $\left(x_{1}^{a}, x_{2}^{a}, \ldots, x_{r}^{a}\right)$, for $a \in A$. Let $N^{A}(C)=N(C) / A$.

Proposition 2.5 [5]. Let $C$ be a fixed ramification type in $G$, and the subset $H_{r}^{A}(C)$ of $H_{r}^{A}(G)$ consists of all $[B, \mathcal{F}]_{A}$ with $Y=\left\{\rho_{1}, \rho_{2}, \ldots \rho_{r}\right\}, \phi: \pi_{1}\left(\mathbb{P}^{1} \backslash Y, \infty\right) \rightarrow G$ and $\phi\left(\sum_{b_{i}}\right) \in C_{i}$ for $i=1, \ldots, r$. Then, $H_{r}^{A}(C)$ is a union of connected components in $H_{r}^{A}(G)$. Under the bijection from Lemma 2.4, the fiber in $H_{r}^{A}(C)$ over $P_{0}$ corresponds to the set $N^{A}(C)$. This yields a one to one correspondence between components of $H_{r}^{A}(C)$ and the braid orbits on $N^{A}(C)$. In particular, $H_{r}^{A}(C)$ is connected if and only if $B_{r}$ acts transitively on $N^{\text {in }}(C)=N(C)$. 
Definition 2.6 [1,8]. Let $\mathrm{G}$ be a group that acts on the set $\mho$. Then, the fixed point ratio of a point $x \in G$ is defined by the set $\left\{\frac{f(x)}{n}\right\}$, where $f(x)$ is the number of fixed points of $x$ on $\mho$ and $\mathrm{n}$ is the size of the set $\mho$.

The least upper bound for all fixed point ratios of $x$ is denoted by $\mathrm{b}(\mathrm{G})$ and defined by $b(G)=$ $\operatorname{Max}\left\{\frac{f(x)}{n}, \mathrm{n}=[\mathrm{K}: \mathrm{M}] ; M \geq G\right\}$ where $\mathrm{K}$ is a group of degree 7 with $\mathrm{F}(\mathrm{K})=\mathrm{G}$, and $x \in K$ acts by right translation on the right cosets of some maximal subgroups $M$ of $M$. Now we will explain by the following example.

Example 2.7: The group $A_{7}$ has the following conjugacy classes of maximal subgroups: $A_{6}, L_{2}(7), S_{5}$, and $\left(A_{4} \times 3\right): 2$. Since index $\left[A_{7}: A_{6}\right]=7$, then the number of fixed points of $g_{i} \in C_{i}$ in $A_{7}$ action by translation on the right coset of $A_{6}$ is $\{3,4,1,1,2,0,0,0\}$. Therefore, the maximal fixed point ratio of $g_{i}$ is equal to $\frac{4}{7}$. Similarly, the maximal fixed point ratio of the conjugacy classes of maximal subgroups $L_{2}(7), S_{5}$ and $\left(A_{4} \times 3\right): 2$ are equal to $\frac{1}{5}, \frac{6}{21}$, and $\frac{1}{5}$, respectively. Hence, the maximal fixed point ratio is $\frac{4}{7}=\mathrm{b}\left(A_{7}\right)$.

For any gnus system $\left(x_{1}, x_{2}, \ldots, x_{r}\right)$ we denote $\hat{x}=\left(x_{1}, x_{2}, \ldots, x_{r}\right), A(\hat{x})=\sum_{i=1}^{r} \frac{d_{i}-1}{d_{i}}$, where $\left|x_{i}\right|=d_{i}$. Next, we present a lemma which was proved by Khudhur [4] .

Lemma 2.8 [8]. Let $G$ be a finite group and $M$ be a Maximal subgroup of $G$. Then, the following holds

1- If $\frac{1}{[G: M]} \sum_{i=1}^{r} \sum_{j}^{d_{i}-1} \frac{f\left(x_{i}^{j}\right)}{d_{i}}<A(\hat{x})-2$, then $\hat{x}$ does not have a genus zero system.

2- If $\frac{1}{[G: M]} \sum_{i=1}^{r} \sum_{j}^{d_{i}-1} \frac{f\left(x_{i}^{j}\right)}{d_{i}} \neq A(\hat{x})-2$, then $\hat{x}$ does not have a genus one system.

3- If $\frac{1}{[G: M]} \sum_{i=1}^{r} \sum_{j}^{d_{i}-1} \frac{f\left(x_{i}^{j}\right)}{d_{i}}>A(\hat{x})-2$, then $\hat{x}$ does not have a genus two system.

In the next lemma, we generalize the above lemma for genus $\mathrm{k}$-system for $\mathrm{k}>2$.

Lemma 2.9: Let $G$ be a finite group and $M$ is a Maximal subgroup of $G$. Then If $\frac{1}{[G: M]} \sum_{i=1}^{r} \sum_{j}^{d_{i}-1} \frac{f\left(x_{i}^{j}\right)}{d_{i}}<A(\hat{x})-2-\frac{2 k}{n}$, then $\hat{x}$ has not a genus k- system.

Proof: Let $\hat{x}$ be a genus k- system, then $\sum_{i=1}^{r}$ ind $x_{i}=2 n+2 k-2$. Since

ind $_{i} \quad=n-\sum_{j=1}^{d_{i}} \frac{f\left(x_{i}^{j}\right)}{d_{i}}=n-\left(\sum_{j=1}^{d_{i-1}} \frac{f\left(x_{i}^{j}\right)}{d_{i}}+\frac{f\left(x_{i}^{d_{i}}\right)}{d_{i}}\right)=n-\frac{n}{d_{i}}-\sum_{j=1}^{d_{i-1}} \frac{f\left(x_{i}^{j}\right)}{d_{i}}=n\left(\frac{d_{i}-1}{d_{i}}\right)-$ $\sum_{j=1}^{d_{i-1}} \frac{f\left(x_{i}^{j}\right)}{d_{i}}$

then we get $\sum_{i=1}^{r}$ ind $x_{i}=n \sum_{i=1}^{r} \frac{d_{i}-1}{d_{i}}-\sum_{i=1}^{r} \sum_{j=1}^{d_{i-1}} \frac{f\left(x_{i}^{j}\right)}{d_{i}}$.

Thus $\frac{1}{n} \sum_{i=1}^{r} \sum_{j=1}^{d_{i-1}} \frac{f\left(x_{i}^{j}\right)}{d_{i}}=\sum_{i=1}^{r} \frac{d_{i}-1}{d_{i}}-\frac{1}{n} \sum_{i=1}^{r} \operatorname{ind} x_{i}=A(\hat{x})-2-\frac{2 k}{n}-\frac{2}{n}$.

which implies that $\frac{1}{[G: M]} \sum_{i=1}^{r} \sum_{j}^{d_{i}-1} \frac{f\left(x_{i}^{j}\right)}{d_{i}}=A(\hat{x})-2-\frac{2 k}{n}-\frac{2}{n}$. Since $[G: M]=n>1$, then if $\frac{1}{[G: M]} \sum_{i=1}^{r} \sum_{j}^{d_{i}-1} \frac{f\left(x_{i}^{j}\right)}{d_{i}}<A(\hat{x})-2-\frac{2 k}{n}$ then the Riemann Hurwitz formula failed. Hence the claim.

Proposition 2.10 [1]. Assume that a group $G$ acts transitively and faithfully on $\Omega$ and $|\Omega|=n$. Let $r \geq 2, G=\left\langle x_{1}, x_{2}, \ldots, x_{r}\right\rangle, \prod_{i}^{r} x_{i}=1$, and $\left|x_{i}\right|=d_{i}>1, i=1, \ldots, r$. Then one of the following holds:

(1) $\sum_{i=1}^{r} \frac{d_{i}-1}{d_{i}} \geq \frac{85}{42}$.

(2) $\mathrm{G}$ is solvable group and $\mathrm{G}$ is of type $(3,3,3),(2,3,6),(2,2, d),(2,4,4)$ or $(2,2,2,2)$.

(3) $r=3$ and (up to permutation) $\left(d_{1}, d_{2}, d_{3}\right)=$

a) $(2,3,3)$ and $G \cong A_{4}$.

b) $(2,3,4)$ and $G \cong S_{4}$.

c) $(2,3,5)$ and $G \cong A_{5}$.

(4) $r=2$ and $G$ is cyclic. 


\section{3- POSSIBLE RAMIFICATION TYPES}

In this section, we find all possible ramification types and use filers to eliminate signature as much as we can. Firstly, we start by using equation 3 to remove the groups $C(7), D(2 * 7)$.

Lemma3.1: Let $\mathrm{G}$ be a group $C(7)$ or $D(2 * 7)$. Then $\mathrm{G}$ possesses no primitive genus one system. Proof: The group $C(7)$ has six conjugacy classes of order 7 but in different types, which are (7A,7B,7C,7D,7E,7F). By using equation 3, we obtain that the group $C(7)$ has not possible ramification types. In other words, we do not have ramification types $\left(\alpha_{1}, \cdots, \alpha_{r}\right)$ such that $\sum_{i=1}^{r}$ ind $\alpha_{i}=14=2(7+1-1)$. Similarly, by using equation 3 , we gain that the group $D(2 * 7)$ has not possible ramification types.

Lemma3.2: Let $G$ be a group $7: 3$ and $\hat{x} \in G^{r}$, where $x_{i}, i=1, \ldots, n$ acts on the right cosets of maximal subgroup of the group 7:3. Then, $r \leq 3$, and if $r=3$ then $x_{1}, x_{2} \in\{3 A, 3 B\}$ and $x_{3} \in$ $\{7 A, 7 B\}$.

Proof: Suppose that $\hat{x}$ is genus one system. Then, by Riemann Hurwitz formula, $\sum_{i=1}^{r}$ ind $x_{i}=$ $2(7+1-1)=14$. Since the indexes of $x_{i}$ in $7: 3$ are $0,4,4,6$, and 6 , which are indexes of $1 \mathrm{~A}, 3 \mathrm{~A}, 3 \mathrm{~B}, 7 \mathrm{~A}$, and 7B, respectively, then $r \leq 3$, and if $r=3$ then $x_{1}, x_{2} \in\{3 A, 3 B\}$ and $x_{3} \in$ $\{7 A, 7 B\}$.

Note that the possible ramification types are $(3 \mathrm{~A}, 3 \mathrm{~A}, 7 \mathrm{~A}),(3 \mathrm{~A}, 3 \mathrm{~A}, 7 \mathrm{~B}),(3 \mathrm{~A}, 3 \mathrm{~B}, 7 \mathrm{~A}),(3 \mathrm{~A}, 3 \mathrm{~B}, 7 \mathrm{~B})$, $(3 \mathrm{~B}, 3 \mathrm{~B}, 7 \mathrm{~A})$, and $(3 \mathrm{~B}, 3 \mathrm{~B}, 7 \mathrm{~B})$. The next lemma allow us to eliminate some of them.

Lemma 3.3: Let $\mathrm{G}$ be a group $7: 3$ and $\hat{x} \in G^{r}$, where $x_{i}, i=1, \ldots, n$ acts on the right cosets of maximal subgroup of the group $7: 3$. Then, $G$ is not of types (3A,3A,7A), (3A,3A,7B), (3B,3B,7A), (3B,3B,7B).

Proof: By using the GAP program, the types $(x, y, z)=(3 A, 3 A, 7 A),(3 A, 3 A, 7 B),(3 B, 3 B, 7 A),(3 B, 3 B, 7 B)$ do not satisfy $x y z=1$. It follows that all of them will be eliminated.

Next, we present the possible ramification type of the group $\operatorname{AGL}(1,7)$. Since the degree operation of AGL $(1,7)$ is equal to seven, then Riemann Hurwitz formula implies that $\sum_{i=1}^{r} i n d x_{i}=14$.

Lemma 3.4: Let $\mathrm{G}$ be a group $\operatorname{AGL}(1,7)$ and $\hat{x} \in G^{r}$, where $x_{i}, i=1, \ldots, n$ acts on the right cosets of the maximal subgroup of the group AGL(1,7). Then, $r \leq 4$ and if $r=4$, then $x_{1}, x_{2} \in\{2 A\} x_{3} \in$ $\{2 A, 3 A, 3 B, 6 A, 6 B\}$ and $x_{4} \in\{3 A, 3 B, 6 A, 6 B\}$.

Proof: Suppose that $\hat{x}$ is genus one system. Then Riemann Hurwitz formula is equivalent to 14 . Since the minimal index $x_{i}$ is equal to 3 , so if $\mathrm{r}=5$, then $\sum_{i=1}^{5} i n d x_{i}=15>14$, which is impossible, then $r \leq 4$. So, if $\mathrm{r}=4$ then $x_{1}, x_{2} \notin\{3 A, 3 B, 6 A, 6 B\}$, otherwise Riemann Hurwitz formula has failed. On the other hand, by $x_{4} \notin\{2 A\}$. Hence, $x_{1}, x_{2} \in\{2 A\}, x_{3} \in\{2 A, 3 A, 3 B, 6 A, 6 B\}$, and $x_{4} \in$ $\{3 A, 3 B, 6 A, 6 B\}$.

By the above lemma, the possible ramification types are $(3 \mathrm{~A}, 6 \mathrm{~A}, 6 \mathrm{~A}),(3 \mathrm{~B}, 6 \mathrm{~A}, 6 \mathrm{~A}),(3 \mathrm{~A}, 6 \mathrm{~A}, 6 \mathrm{~B})$, $(3 \mathrm{~B}, 6 \mathrm{~A}, 6 \mathrm{~B}),(3 \mathrm{~B}, 6 \mathrm{~B}, 6 \mathrm{~B}) \quad(3 \mathrm{~A}, 3 \mathrm{~A}, 7 \mathrm{~A}), \quad(3 \mathrm{~B}, 3 \mathrm{~B}, 7 \mathrm{~A}), \quad(3 \mathrm{~A}, 3 \mathrm{~B}, 7 \mathrm{~A}), \quad(3 \mathrm{~A}, 6 \mathrm{~B}, 6 \mathrm{~B})$, $(2 \mathrm{~A}, 6 \mathrm{~A}, 7 \mathrm{~A}),(2 \mathrm{~A}, 6 \mathrm{~B}, 7 \mathrm{~A}),(2 \mathrm{~A}, 2 \mathrm{~A}, 3 \mathrm{~A}, 3 \mathrm{~A}),(2 \mathrm{~A}, 2 \mathrm{~A}, 2 \mathrm{~A}, 6 \mathrm{~A}) \quad,(2 \mathrm{~A}, 2 \mathrm{~A}, 3 \mathrm{~A}, 3 \mathrm{~B}), \quad(2 \mathrm{~A}, 2 \mathrm{~A}, 2 \mathrm{~A}, 6 \mathrm{~B}) \quad$, $(2 \mathrm{~A}, 2 \mathrm{~A}, 3 \mathrm{~B}, 3 \mathrm{~B})$.

Lemma 3.5: Let $\mathrm{G}$ be a group $\operatorname{AGL}(1,7)$ and $\hat{x} \in G^{r}$, where $x_{i}, i=1, \ldots, n$ acts on the right cosets of the maximal subgroup of the group AGL(1,7). Then $\mathrm{G}$ is not of the type (3A,6A,6A), (3A,6A,6B), $(3 \mathrm{~B}, 6 \mathrm{~A}, 6 \mathrm{~B}),(3 \mathrm{~B}, 6 \mathrm{~B}, 6 \mathrm{~B}) \quad(3 \mathrm{~A}, 3 \mathrm{~A}, 7 \mathrm{~A}), \quad(3 \mathrm{~B}, 3 \mathrm{~B}, 7 \mathrm{~A})$,

$(2 \mathrm{~A}, 6 \mathrm{~A}, 7 \mathrm{~A}),(2 \mathrm{~A}, 6 \mathrm{~B}, 7 \mathrm{~A}),(2 \mathrm{~A}, 2 \mathrm{~A}, 3 \mathrm{~A}, 3 \mathrm{~A}),(2 \mathrm{~A}, 2 \mathrm{~A}, 2 \mathrm{~A}, 6 \mathrm{~A}),(2 \mathrm{~A}, 2 \mathrm{~A}, 2 \mathrm{~A}, 6 \mathrm{~B}),(2 \mathrm{~A}, 2 \mathrm{~A}, 3 \mathrm{~B}, 3 \mathrm{~B})$.

Proof: Suppose that $z$ is representative of conjugacy classes of order seven of type A. Then, there are 6 conjugacy classes of the pair $(x, y)$, such that the product of $x$ and $y$ is equal to inverse $z$, where $\mathrm{x}$ and $\mathrm{y}$ are representatives of the conjugacy classes of order three of types A and B, respectively. However, the order of the group generated by the pair $(x, y)$ is not equal to the group AGL $(1,7)$. Hence, the triple $(3 \mathrm{~A}, 3 \mathrm{~B}, 7 \mathrm{~A})$ will be ruled out. A GAP calculation shows that the group algebra structure constants [4] of (3A,6A,6A), (3A,6A,6B), (3B,6A,6B), (3B,6B,6B) (3A,3A,7A), (3B,3B,7A), $(2 \mathrm{~A}, 6 \mathrm{~A}, 7 \mathrm{~A}),(2 \mathrm{~A}, 6 \mathrm{~B}, 7 \mathrm{~A}),(2 \mathrm{~A}, 2 \mathrm{~A}, 3 \mathrm{~A}, 3 \mathrm{~A}),(2 \mathrm{~A}, 2 \mathrm{~A}, 2 \mathrm{~A}, 6 \mathrm{~A}),(2 \mathrm{~A}, 2 \mathrm{~A}, 2 \mathrm{~A}, 6 \mathrm{~B}),(2 \mathrm{~A}, 2 \mathrm{~A}, 3 \mathrm{~B}, 3 \mathrm{~B})$ are equal to zero. Thus, they will be cancelled.

The above arguments imply that the ramification types $(3 \mathrm{~B}, 6 \mathrm{~A}, 6 \mathrm{~A}),(3 \mathrm{~A}, 6 \mathrm{~B}, 6 \mathrm{~B}),(2 \mathrm{~A}, 2 \mathrm{~A}, 3 \mathrm{~A}, 3 \mathrm{~B})$ will remain.

Note that the group $L(3,2)$ is of order 168 and it has elements of order 1,2,3,4 and 7 [3]. The group 
$L(3,2)$ acts 2-transitively on seven and eight points. Furthermore, it has two classes of maximal subgroups, which are the symmetric group $S_{4}$ and 7:3. To determine the list of possible ramification types, we first use the GAP program to find the action of representative $x_{i}$ of conjugacy classes of $L(3,2)$ on the right cosets of the maximal subgroups $S_{4}$ and 7:3.

Lemma 3.6: Let $\mathrm{G}$ be a group $L(3,2)$ and $\hat{x} \in G^{r}$, where $x_{i}, i=1, \ldots, n$, acts on the right cosets of the maximal subgroup $S_{4}$. Then, $r \leq 7$ and, if $r=7$, then $x_{1}, x_{2} \ldots x_{7} \in\{2 A\}$.

Proof: Similar to proof 3.4, by using Riemann Hurwitz formula, we obtain the result.

By the above lemma, the group $L(3,2)$ has 25 possible ramification types when it acts on the right coset of the maximal subgroup $S_{4}$. One of these ramification types will be cancelled, which is (2A,7A,7B), because its group algebra structure constant is equal to zero. So, the 24 ramification type cannot be ruled out, as presented in table 1 .

Lemma 3.7: Let $\mathrm{G}$ be a group $L(3,2)$ and $\hat{x} \in G^{r}$, where $x_{i}, i=1, \ldots, n$ acts on the right cosets of the maximal subgroup 7:3. Then, $r \leq 4$ and, if $r=4$, then $x_{1}, x_{2} \ldots x_{4} \in\{2 A, 3 A\}$.

Proof: Similar to proof 3.4, by using Riemann Hurwitz formula, we obtain the result.

Group $L(3,2)$ has 17 possible ramification types when it acts on the right coset of subgroup 7:3. However, four of these ramification types will be cancelled, which are $(2 \mathrm{~A}, 4 \mathrm{~A}, 4 \mathrm{~A}),(2 \mathrm{~A}, 7 \mathrm{~A}, 7 \mathrm{~B})$, $(2 \mathrm{~A}, 2 \mathrm{~A}, 2 \mathrm{~A}, 3 \mathrm{~A})$, and $(2 \mathrm{~A}, 2 \mathrm{~A}, 2 \mathrm{~A}, 2 \mathrm{~A})$. By proposition 2.10 , types $(2 \mathrm{~A}, 4 \mathrm{~A}, 4 \mathrm{~A})$ and $(2 \mathrm{~A}, 2 \mathrm{~A}, 2 \mathrm{~A}, 2 \mathrm{~A})$ are solvable groups, then they will be ruled out. Finally, the group algebra structure constants of $(2 \mathrm{~A}, 2 \mathrm{~A}, 2 \mathrm{~A}, 3 \mathrm{~A})$ and $(2 \mathrm{~A}, 7 \mathrm{~A}, 7 \mathrm{~B})$ are equal to zero, hence they will be removed. So, 13 ramification types cannot be ignored, which are presented in table 2 .

The final group with which we work in this paper is the alternating group $A_{7}$. The group $A_{7}$ is of order 2520 and has elements of order 1,2,3,4,5,6 and 7 [3]. It acts 5-transitively on 7 points. The group $A_{7}$ has four classes of maximal subgroups, which are $A_{6}, L_{2}(7), S_{5}$ and $\left(A_{4} \times 3\right): 2$ [3]. To determine the list of possible ramification types, similar to the group $L(3,2)$, we first find, using GAP program, the action of representative $x_{i}$ of conjugacy classes of $A_{7}$ on the right cosets of the maximal subgroups $A_{6}, L_{2}(7), S_{5}$ and $\left(A_{4} \times 3\right): 2$.

Lemma3.8: Let $\mathrm{G}$ be a group $A_{7}$ and $\hat{x} \in G^{r}$, where $x_{i}, i=1, \ldots, n$ acts on the right cosets of the maximal subgroup $A_{6}$. Then, $r \leq 7$ and, if $r=7$, then $x_{1}, x_{2} \ldots x_{7} \in\{2 A, 3 A\}$.

Proof: Similar to proof 3.4, by using Riemann Hurwitz formula, we obtain the result.

Lemma3.9: Let $\mathrm{G}$ be a group $A_{7}$ and $\hat{x} \in G^{r}$, where $x_{i}, i=1, \ldots, n$ acts on the right cosets of the maximal subgroup $L_{2}(7)$ and $S_{5}$. Then, $r \leq 4$.

Proof: Similar to proof 3.4, by using Riemann Hurwitz formula, we obtain the result.

Lemma3.10: Let $\mathrm{G}$ be a group $A_{7}$ and $\hat{x} \in G^{r}$, where $x_{i}, i=1, \ldots, n$ acts on the right cosets of the maximal subgroup $\left(A_{4} \times 3\right): 2$. . Then, $r \leq 3$.

Proof: Similar to proof 3.4, by using Riemann Hurwitz formula, we obtain the result.

By Riemann Hurwitz formula, group $A_{7}$, when acts on the right cosets of the maximal subgroup $A_{6}$, has 172 possible ramification types, such that two of them will be removed by using the filter. In table 3 , all the generating ramification types are presented. Similarly, by using Riemann Hurwitz formula, the group $A_{7}$ has 30,26, and 12 possible ramification types when it acts on the right cosets of the maximal subgroups $L_{2}(7), S_{5}$ and $\left(A_{4} \times 3\right): 2$, respectively. So, the numbers of the ramification types of $A_{7}$ which are passing the filter are 18,18 , and 4 , when acting on the maximal subgroups $L_{2}(7), S_{5}$ and $\left(A_{4} \times 3\right): 2$, respectively.

4- Proof of Theorem 2

The purpose of this section is to prove theorem 2. For the groups of degree 7, we have a complete list of admissible genus one tuples. The groups of degree 7 are $C(7), D(2 * 7), 7: 3, A G L(1,7), L(3,2), A_{7}$ and $S_{7}$ [3]. In this step, we do not study the group $S_{7}$ because its tuples are too large so that our computers cannot compute the braid orbits. By lemma 3.1 , we removed the groups $C(7), D(2 * 7)$. So, the four groups of $7: 3, A G L(1,7), L(3,2)$ and $A_{7}$ remained.

The first step in this process is to find a list of representative conjugacy classes. In the next step, we give for each group the set of permutation indices. This set determines the tuples which satisfy Riemann Hurwitz formula. The filters presented in section two provided us with the generated ramification types. Next, by using MapClass, we determined the number of components of the Hurwitz spaces, $H_{r}^{i n}(C)$. Now, we give the following lemmas. 
Lemma 4.1: For the group 7:3, the Hurwitz spaces, $H_{r}^{i n}(C)$, are connected and $r=3$.

Proof: By Lemma 3.2, r=3. So, all ramification types $\mathrm{C}$ of the group 7:3 of length 3. Furthermore, all types $\mathrm{C}$ which is presented in Table1 up to permutation has only one braid orbit on Nielsen classes $N(7: 3, C)$. From Proposition 2.5, we obtain that the Hurwitz spaces $H_{r}^{i n}(C)$ are connected.

Lemma 4.2: For the group AGL(1,7), the Hurwitz spaces, $H_{r}^{\text {in }}(C)$, are connected if $r=3$ or $r=4$. Proof : By Lemma 3.4, $r \leq 4$ and, if $r \leq 2$, then by Proposition 2.10, $\mathrm{G}$ is a cyclic group, hence it will be eliminated. So, all ramification types $\mathrm{C}$ are of the length three or four. From Table 2, we observe that all ramification types $\mathrm{C}$ up to permutation has only one braid orbit on the Nielsen classes $N(\operatorname{AGL}(1,7), C)$. So, the Hurwitz spaces $H_{r}^{i n}(C)$ has one component. It follows from the Proposition 2.5 that the Hurwitz spaces $H_{r}^{i n}(C)$ are connected.

Lemma 4.3: For the group L(3,2), the Hurwitz spaces, $H_{r}^{i n}(C)$, are disconnected if $r=3$ and $n=7$. Proof : By lemma 3.6, the group L(3,2), when it acts on the right coset of the maximal subgroup $S_{4}$, has a ramification type of length $r \leq 7$. If $r \leq 2$, then by proposition $2.10, \mathrm{G}$ is cyclic group, and then it will be eliminated. Hence, the length of the ramification types is between $3 \leq r \leq 7$. As shown in Table 3 , the types $C=(3 \mathrm{~A}, 4 \mathrm{~A}, 7 \mathrm{~A})$ and $\mathrm{C}=(3 \mathrm{~A}, 4 \mathrm{~A}, 7 \mathrm{~B})$ have two braid orbits on Nielsen classes $N(\mathrm{~L}(3,2), C)$, which implies that the Hurwitz spaces $H_{r}^{\text {in }}(C)$ has two components. By Proposition 2.5, we obtain that the Hurwitz spaces $H_{r}^{i n}(C)$ are disconnected.

Lemma 4.4: For the group L(3,2), the Hurwitz spaces $H_{r}^{i n}(C)$ are connected if $r \geq 4$ and $n=7$.

Proof: It follows from the fact that the Nielsen classes $N(C)$ are the disjoint union of braid orbits, but for $\mathrm{L}(3,2)$ we have only one braid orbit for all types $C$, as given in Table 3. From Proposition 2.5, we obtain that the Hurwitz spaces $H_{r}^{i n}(C)$ are connected.

Lemma 4.5: For the group $\mathrm{L}(3,2)$, the Hurwitz spaces $H_{r}^{i n}(C)$ are disconnected if $r \geq 3$ and $n=8$. Proof: By Lemma 3.7, $r \leq 4$. This means that the length of ramification types is between $3 \leq r \leq 4$. Since some type $\mathrm{C}$ ramifications in Table 4 have two braid orbits on Nielsen classes $N(\mathrm{~L}(3,2), C)$, the Hurwitz spaces $H_{r}^{i n}(C)$ have two components. By proposition 2.5, we obtain that the Hurwitz spaces $H_{r}^{\text {in }}(C)$ are disconnected.

Lemma 4.6: For the group $A_{7}$, the Hurwitz spaces $H_{r}^{i n}(C)$ are disconnected if $r \geq 3$ and $n=7$.

Proof :By Lemma 3.8, $r \leq 7$. Since some type $\mathrm{C}$ ramifications in Table 5 have at least two braid orbits on Nielsen classes $N\left(A_{7}, C\right)$, the Hurwitz spaces $H_{r}^{i n}(C)$ have at least two components. By Proposition 2.5, we obtain that the Hurwitz spaces $H_{r}^{i n}(C)$ are disconnected.

Note that the Hurwitz spaces for all of ramification types $\mathrm{C}$ of group $A_{7}$ are disconnected when $A_{7}$ acts on the right coset of the maximal subgroup $A_{6}$.

Lemma 4.7: For the group $A_{7}$, the Hurwitz spaces $H_{r}^{i n}(C)$ are disconnected if $r \geq 3$ and $n=15$.

Proof :By Lemma 3.9, $r \leq 4$. Similar to above, when $A_{7}$ acts on the right cosets of the maximal subgroup $L_{2}(7)$, it has at least two braid orbits for some types $C$ on Nielsen classes $N\left(A_{7}, C\right)$, as given in Table 6. Therefore, the Hurwitz spaces $H_{r}^{i n}(C)$ has at least two components. By proposition 2.5, we obtain that the Hurwitz spaces $H_{r}^{i n}(C)$ are disconnected.

Lemma 4.8: For the group $A_{7}$, the Hurwitz spaces $H_{r}^{i n}(C)$ are disconnected if $r=3$ and connected if $\mathrm{r}=4$ where $n=21$.

Proof :By lemma 3.9, $r \leq 4$. Thus the length of the ramification types $\mathrm{C}$ of, $A_{7}$ when acts on the right cosets of maximal subgroup $S_{5}$ between $3 \leq r \leq 4$. Now if $\mathrm{r}=3$, then $A_{7}$ has at least two braid orbits for some types $\mathrm{C}$ on Nielsen classes $N\left(A_{7}, C\right)$. However, if $\mathrm{r}=4$, then $A_{7}$ has one braid orbits for all types $\mathrm{C}$ on Nielsen classes $N\left(A_{7}, C\right)$, as a presented in Table7. From Proposition 2.5, we obtain that the Hurwitz spaces $H_{r}^{\text {in }}(C)$ are disconnected if $\mathrm{r}=3$ and connected if $\mathrm{r}=4$.

Lemma 4.9: For the group $A_{7}$, the Hurwitz spaces $H_{r}^{i n}(C)$ are disconnected if $r=3$ and $n=35$.

Proof :By Lemma 3.10, $r \leq 3$. It follows that the group $A_{7}$ has four ramification types of length 3 , as shown in Table 8. Note that all types have at least two braid orbits on Nielsen classes $N\left(A_{7}, C\right)$. Therefore, the Hurwitz spaces $H_{r}^{\text {in }}(C)$ have at least two components. Hence, by Proposition 2.5, we obtain that the Hurwitz spaces $H_{r}^{i n}(C)$ are disconnected for all type $\mathrm{C}$.

Proof of Theorem 2: By Lemmas 4.1 to 4.9, we could obtain the results in Tables-(1 to 8). 
Table 1-Connected Components $\mathcal{H}_{r, 1}^{\text {in }}(C)$ of 7:3

\begin{tabular}{|c|c|c|c|c|c|c|}
\hline Group & $\begin{array}{c}\text { Ramification } \\
\text { type }\end{array}$ & $\begin{array}{c}\text { N. of } \\
\text { orbits }\end{array}$ & $\begin{array}{c}\text { Length of } \\
\text { orbits }\end{array}$ & $\begin{array}{c}\text { Ramificatio } \\
\text { n type }\end{array}$ & $\begin{array}{c}\text { N. of } \\
\text { orbits }\end{array}$ & $\begin{array}{c}\text { Length of } \\
\text { orbits }\end{array}$ \\
\hline $7: 3$ & $(3 \mathrm{~A}, 3 \mathrm{~B}, 7 \mathrm{~A})$ & 1 & 1 & $(3 \mathrm{~A}, 3 \mathrm{~B}, 7 \mathrm{~B})$ & 1 & 1 \\
\hline
\end{tabular}

Table 2- Connected Components $\mathcal{H}_{r, 1}^{\text {in }}(C)$ of $\operatorname{AGL}(1,7)$

\begin{tabular}{|c|c|c|c|c|c|c|}
\hline Group & $\begin{array}{c}\text { Ramification } \\
\text { type }\end{array}$ & $\begin{array}{l}\text { N. of } \\
\text { orbits }\end{array}$ & $\begin{array}{c}\text { Length of } \\
\text { orbits }\end{array}$ & $\begin{array}{c}\text { Ramification } \\
\text { type }\end{array}$ & $\begin{array}{l}\text { N. of } \\
\text { orbits }\end{array}$ & Length of orbits \\
\hline \multirow[b]{2}{*}{$\operatorname{AGL}(1,7)$} & $(3 \mathrm{~B}, 6 \mathrm{~A}, 6 \mathrm{~A})$ & 1 & 1 & $(3 \mathrm{~A}, 6 \mathrm{~B}, 6 \mathrm{~B})$ & 1 & 1 \\
\hline & $\begin{array}{c}(2 \mathrm{~A}, 2 \mathrm{~A}, 3 \mathrm{~A}, 3 \\
\mathrm{B})\end{array}$ & 1 & 8 & & & \\
\hline
\end{tabular}

Table 3-Connected Components $\mathcal{H}_{r, 1}^{\text {in }}(C)$ of $\mathrm{L}(3,2), \mathrm{n}=7$.

\begin{tabular}{|c|c|c|c|c|c|c|}
\hline Group & Ramification type & $\begin{array}{l}\text { N. of } \\
\text { orbits }\end{array}$ & $\begin{array}{c}\text { Length } \\
\text { of } \\
\text { orbits }\end{array}$ & Ramification type & $\begin{array}{l}\text { N. of } \\
\text { orbits }\end{array}$ & $\begin{array}{l}\text { Length of } \\
\text { orbits }\end{array}$ \\
\hline \multirow{12}{*}{$L(3,2)$} & $(3 \mathrm{~A}, 3 \mathrm{~A}, 7 \mathrm{~A})$ & 1 & 1 & $(3 \mathrm{~A}, 3 \mathrm{~A}, 7 \mathrm{~B})$ & 1 & 1 \\
\hline & $(3 \mathrm{~A}, 4 \mathrm{~A}, 7 \mathrm{~A})$ & 2 & 1 & $(3 \mathrm{~A}, 4 \mathrm{~A}, 7 \mathrm{~B})$ & 2 & 1 \\
\hline & $(4 \mathrm{~A}, 4 \mathrm{~A}, 7 \mathrm{~A})$ & 1 & 1 & $(4 \mathrm{~A}, 4 \mathrm{~A}, 7 \mathrm{~B})$ & 1 & 1 \\
\hline & $(2 \mathrm{~A}, 7 \mathrm{~A}, 7 \mathrm{~A})$ & 1 & 1 & $(2 \mathrm{~A}, 7 \mathrm{~B}, 7 \mathrm{~B})$ & 1 & 1 \\
\hline & $(2 \mathrm{~A}, 3 \mathrm{~A}, 3 \mathrm{~A}, 3 \mathrm{~A})$ & 1 & 120 & $(2 \mathrm{~A}, 3 \mathrm{~A}, 3 \mathrm{~A}, 4 \mathrm{~A})$ & 1 & 84 \\
\hline & $(2 \mathrm{~A}, 3 \mathrm{~A}, 4 \mathrm{~A}, 4 \mathrm{~A})$ & 1 & 66 & $(2 \mathrm{~A}, 4 \mathrm{~A}, 4 \mathrm{~A}, 4 \mathrm{~A})$ & 1 & 36 \\
\hline & $(2 \mathrm{~A}, 2 \mathrm{~A}, 3 \mathrm{~A}, 7 \mathrm{~B})$ & 1 & 21 & $(2 \mathrm{~A}, 2 \mathrm{~A}, 3 \mathrm{~A}, 7 \mathrm{~A})$ & 1 & 21 \\
\hline & $(2 \mathrm{~A}, 2 \mathrm{~A}, 4 \mathrm{~A}, 7 \mathrm{~B})$ & 1 & 14 & $(2 \mathrm{~A}, 2 \mathrm{~A}, 4 \mathrm{~A}, 7 \mathrm{~A})$ & 1 & 14 \\
\hline & $(2 \mathrm{~A}, 2 \mathrm{~A}, 2 \mathrm{~A}, 3 \mathrm{~A}, 3 \mathrm{~A})$ & 1 & 864 & $(2 \mathrm{~A}, 2 \mathrm{~A}, 2 \mathrm{~A}, 3 \mathrm{~A}, 4 \mathrm{~A})$ & 1 & 648 \\
\hline & $(2 \mathrm{~A}, 2 \mathrm{~A}, 2 \mathrm{~A}, 4 \mathrm{~A}, 4 \mathrm{~A})$ & 1 & 456 & $(2 \mathrm{~A}, 2 \mathrm{~A}, 2 \mathrm{~A}, 2 \mathrm{~A}, 7 \mathrm{~A})$ & 1 & 147 \\
\hline & $(2 \mathrm{~A}, 2 \mathrm{~A}, 2 \mathrm{~A}, 2 \mathrm{~A}, 7 \mathrm{~B})$ & 1 & 147 & $(2 \mathrm{~A}, 2 \mathrm{~A}, 2 \mathrm{~A}, 2 \mathrm{~A}, 2 \mathrm{~A}, 3 \mathrm{~A})$ & 1 & 6480 \\
\hline & $\begin{array}{c}(2 \mathrm{~A}, 2 \mathrm{~A}, 2 \mathrm{~A}, 2 \mathrm{~A}, 2 \mathrm{~A}, 4 \\
\mathrm{A})\end{array}$ & 1 & 4800 & $(2 \mathrm{~A}, 2 \mathrm{~A}, 2 \mathrm{~A} .2 \mathrm{~A}, 2 \mathrm{~A}, 2 \mathrm{~A}, 2 \mathrm{~A})$ & 1 & 48960 \\
\hline
\end{tabular}

Table 4- Connected Components $\mathcal{H}_{r, 1}^{\text {in }}(C)$ of $\mathrm{L}(3,2), \mathrm{n}=8$.

\begin{tabular}{|c|c|c|c|c|c|c|}
\hline \multirow{2}{*}{ Group } & $\begin{array}{c}\text { Ramification } \\
\text { type }\end{array}$ & $\begin{array}{c}\text { N. of } \\
\text { orbits }\end{array}$ & $\begin{array}{c}\text { Length of } \\
\text { orbits }\end{array}$ & $\begin{array}{c}\text { Ramification } \\
\text { type }\end{array}$ & $\begin{array}{c}\text { N. of } \\
\text { orbits }\end{array}$ & $\begin{array}{c}\text { Length of } \\
\text { orbits }\end{array}$ \\
\hline \multirow{5}{*}{$\mathrm{L}(3,2)$} & $(2 \mathrm{~A}, 4 \mathrm{~A}, 7 \mathrm{~A})$ & 1 & 1 & $(2 \mathrm{~A}, 4 \mathrm{~A}, 7 \mathrm{~B})$ & 1 & 1 \\
\cline { 2 - 7 } & $(2 \mathrm{~A}, 7 \mathrm{~A}, 7 \mathrm{~A})$ & 1 & 1 & $(2 \mathrm{~A}, 7 \mathrm{~B}, 7 \mathrm{~B})$ & 1 & 1 \\
\cline { 2 - 7 } & $(3 \mathrm{~A}, 4 \mathrm{~A}, 4 \mathrm{~A})$ & 2 & 1 & $(3 \mathrm{~A}, 4 \mathrm{~A}, 7 \mathrm{~A})$ & 2 & 1 \\
\cline { 2 - 7 } & $(3 \mathrm{~A}, 7 \mathrm{~A}, 7 \mathrm{~A})$ & 1 & 1 & $(3 \mathrm{~A}, 4 \mathrm{~A}, 7 \mathrm{~B})$ & 2 & 1 \\
\cline { 2 - 7 } & $(3 \mathrm{~A}, 7 \mathrm{~A}, 7 \mathrm{~B})$ & 1 & 1 & $(3 \mathrm{~A}, 7 \mathrm{~B}, 7 \mathrm{~B})$ & 1 & 1 \\
\cline { 2 - 7 } & $(2 \mathrm{~A}, 2 \mathrm{~A}, 3 \mathrm{~A}, 3 \mathrm{~A})$ & 1 & 30 & $(2 \mathrm{~A}, 3 \mathrm{~A}, 3 \mathrm{~A}, 3 \mathrm{~A})$ & 1 & 120 \\
\hline
\end{tabular}

Table 5- Connected Components $\mathcal{H}_{r, 1}^{\text {in }}(C)$ of $A_{7}, \mathrm{n}=7$

\begin{tabular}{|c|c|c|c|c|c|c|}
\hline $\begin{array}{c}\text { Gro } \\
\text { up }\end{array}$ & Ramification type & $\begin{array}{c}\text { N. of } \\
\text { orbits }\end{array}$ & $\begin{array}{c}\text { Length of } \\
\text { orbits }\end{array}$ & Ramification type & $\begin{array}{c}\text { N. of } \\
\text { orbits }\end{array}$ & $\begin{array}{c}\text { Length of } \\
\text { orbits }\end{array}$ \\
\hline \multirow{6}{*}{} & {$[5 \mathrm{~A}, 5 \mathrm{~A}, 7 \mathrm{~A}]$} & 12 & 1 & {$[5 \mathrm{~A}, 5 \mathrm{~A}, 7 \mathrm{~B}]$} & 12 & 1 \\
\cline { 2 - 7 } & {$[4 \mathrm{~A}, 5 \mathrm{~A}, 7 \mathrm{~A}]$} & 18 & 1 & {$[4 \mathrm{~A}, 5 \mathrm{~A}, 7 \mathrm{~B}]$} & 18 & 1 \\
\cline { 2 - 7 }$A_{7}$ & {$[4 \mathrm{~A}, 4 \mathrm{~A}, 7 \mathrm{~A}]$} & 22 & 1 & {$[4 \mathrm{~A}, 4 \mathrm{~A}, 7 \mathrm{~B}]$} & 22 & 1 \\
\cline { 2 - 7 } & {$[3 \mathrm{~B}, 5 \mathrm{~A}, 7 \mathrm{~A}]$} & 8 & 1 & {$[3 \mathrm{~B}, 5 \mathrm{~A}, 7 \mathrm{~B}]$} & 8 & 1 \\
\cline { 2 - 7 } & {$[3 \mathrm{~B}, 4 \mathrm{~A}, 7 \mathrm{~A}]$} & 6 & 1 & {$[3 \mathrm{~B}, 4 \mathrm{~A}, 7 \mathrm{~B}]$} & 6 & 1 \\
\cline { 2 - 7 } & {$[5 \mathrm{~A}, 6 \mathrm{~A}, 7 \mathrm{~A}]$} & 7 & 1 & {$[5 \mathrm{~A}, 6 \mathrm{~A}, 7 \mathrm{~B}]$} & 7 & 1 \\
\cline { 2 - 7 } & {$[4 \mathrm{~A}, 6 \mathrm{~A}, 7 \mathrm{~A}]$} & 8 & 1 & {$[4 \mathrm{~A}, 6 \mathrm{~A}, 7 \mathrm{~B}]$} & 8 & 1 \\
\cline { 2 - 7 } & {$[3 \mathrm{~B}, 6 \mathrm{~A}, 7 \mathrm{~A}]$} & 3 & 1 & {$[3 \mathrm{~B}, 6 \mathrm{~A}, 7 \mathrm{~B}]$} & 3 & 1 \\
\cline { 2 - 7 } & {$[6 \mathrm{~A}, 6 \mathrm{~A}, 7 \mathrm{~A}]$} & 2 & 1 & {$[6 \mathrm{~A}, 6 \mathrm{~A}, 7 \mathrm{~B}]$} & 2 & 1 \\
\hline
\end{tabular}




\begin{tabular}{|c|c|c|c|c|c|}
\hline$[3 \mathrm{~A}, 7 \mathrm{~B}, 7 \mathrm{~B}]$ & 2 & 1 & {$[2 \mathrm{~A}, 7 \mathrm{~A}, 7 \mathrm{~A}]$} & 2 & 1 \\
\hline$[2 \mathrm{~A}, 7 \mathrm{~A}, 7 \mathrm{~B}]$ & 1 & 1 & {$[2 \mathrm{~A}, 7 \mathrm{~B}, 7 \mathrm{~B}]$} & 2 & 1 \\
\hline$[3 \mathrm{~A}, 5 \mathrm{~A}, 5 \mathrm{~A}, 5 \mathrm{~A}]$ & 2 & 450,180 & {$[3 \mathrm{~A}, 4 \mathrm{~A}, 5 \mathrm{~A}, 5 \mathrm{~A}]$} & 2 & 600,600 \\
\hline$[3 \mathrm{~A}, 4 \mathrm{~A}, 4 \mathrm{~A}, 5 \mathrm{~A}]$ & 2 & 600,600 & {$[3 \mathrm{~A}, 4 \mathrm{~A}, 4 \mathrm{~A}, 4 \mathrm{~A}]$} & 2 & 1260,1260 \\
\hline$[3 \mathrm{~A}, 3 \mathrm{~B}, 5 \mathrm{~A}, 5 \mathrm{~A}]$ & 2 & 180,330 & {$[3 \mathrm{~A}, 3 \mathrm{~B}, 4 \mathrm{~A}, 5 \mathrm{~A}]$} & 2 & 410,410 \\
\hline$[3 \mathrm{~A}, 3 \mathrm{~B}, 4 \mathrm{~A}, 4 \mathrm{~A}]$ & 2 & 532,590 & {$[3 \mathrm{~A}, 3 \mathrm{~B}, 3 \mathrm{~B}, 5 \mathrm{~A}]$} & 2 & 240,130 \\
\hline$[3 \mathrm{~A}, 3 \mathrm{~B}, 3 \mathrm{~B}, 4 \mathrm{~A}]$ & 2 & 248,248 & {$[3 \mathrm{~A}, 3 \mathrm{~B}, 3 \mathrm{~B}, 3 \mathrm{~B}]$} & 3 & $126,42,42$ \\
\hline$[3 \mathrm{~A}, 5 \mathrm{~A}, 5 \mathrm{~A}, 6 \mathrm{~A}]$ & 1 & 550 & {$[3 \mathrm{~A}, 4 \mathrm{~A}, 5 \mathrm{~A}, 6 \mathrm{~A}]$} & 1 & 700 \\
\hline$[3 \mathrm{~A}, 4 \mathrm{~A}, 4 \mathrm{~A}, 6 \mathrm{~A}]$ & 1 & 894 & {$[3 \mathrm{~A}, 3 \mathrm{~B}, 5 \mathrm{~A}, 6 \mathrm{~A}]$} & 1 & 330 \\
\hline$[3 \mathrm{~A}, 3 \mathrm{~B}, 4 \mathrm{~A}, 6 \mathrm{~A}]$ & 1 & 408 & {$[3 \mathrm{~A}, 3 \mathrm{~B}, 3 \mathrm{~B}, 6 \mathrm{~A}]$} & 1 & 188 \\
\hline$[3 \mathrm{~A}, 5 \mathrm{~A}, 6 \mathrm{~A}, 6 \mathrm{~A}]$ & 1 & 230 & {$[3 \mathrm{~A}, 5 \mathrm{~A}, 4 \mathrm{~A}, 6 \mathrm{~A}]$} & 1 & 304 \\
\hline$[3 \mathrm{~A}, 3 \mathrm{~B}, 6 \mathrm{~A}, 6 \mathrm{~A}]$ & 1 & 130 & {$[3 \mathrm{~A}, 6 \mathrm{~A}, 6 \mathrm{~A}, 6 \mathrm{~A}]$} & 1 & 102 \\
\hline$[3 \mathrm{~A}, 3 \mathrm{~A}, 5 \mathrm{~A}, 7 \mathrm{~A}]$ & 2 & 35,70 & {$[3 \mathrm{~A}, 3 \mathrm{~A}, 5 \mathrm{~A}, 7 \mathrm{~B}]$} & 2 & 35,70 \\
\hline$[3 \mathrm{~A}, 3 \mathrm{~A}, 4 \mathrm{~A}, 7 \mathrm{~A}]$ & 2 & 84,84 & {$[3 \mathrm{~A}, 3 \mathrm{~A}, 4 \mathrm{~A}, 7 \mathrm{~B}]$} & 2 & 84,84 \\
\hline$[3 \mathrm{~A}, 3 \mathrm{~A}, 3 \mathrm{~B}, 7 \mathrm{~A}]$ & 2 & 49,28 & {$[3 \mathrm{~A}, 3 \mathrm{~A}, 3 \mathrm{~B}, 7 \mathrm{~B}]$} & 2 & 49,28 \\
\hline$[3 \mathrm{~A}, 3 \mathrm{~A}, 6 \mathrm{~A}, 7 \mathrm{~A}]$ & 1 & 70 & {$[3 \mathrm{~A}, 3 \mathrm{~A}, 6 \mathrm{~A}, 7 \mathrm{~B}]$} & 1 & 70 \\
\hline$[2 \mathrm{~A}, 4 \mathrm{~A}, 5 \mathrm{~A}, 5 \mathrm{~A}]$ & 2 & 660,640 & {$[2 \mathrm{~A}, 5 \mathrm{~A}, 5 \mathrm{~A}, 5 \mathrm{~A}]$} & 3 & $\begin{array}{c}360,480,3 \\
60\end{array}$ \\
\hline$[2 \mathrm{~A}, 2 \mathrm{~A}, 6 \mathrm{~A}, 7 \mathrm{~B}]$ & 3 & $56,56,28$ & {$[2 \mathrm{~A}, 4 \mathrm{~A}, 4 \mathrm{~A}, 5 \mathrm{~A}]$} & 3 & $\begin{array}{c}960,960,9 \\
60\end{array}$ \\
\hline$[2 \mathrm{~A}, 4 \mathrm{~A}, 4 \mathrm{~A}, 4 \mathrm{~A}]$ & 3 & $\begin{array}{c}1260,1260 \\
1248\end{array}$ & {$[2 \mathrm{~A}, 3 \mathrm{~B}, 4 \mathrm{~A}, 4 \mathrm{~A}]$} & 1 & 1548 \\
\hline$[2 \mathrm{~A}, 3 \mathrm{~B}, 5 \mathrm{~A}, 5 \mathrm{~A}]$ & 1 & 900 & {$[2 \mathrm{~A}, 3 \mathrm{~B}, 4 \mathrm{~A}, 5 \mathrm{~A}]$} & 1 & 1290 \\
\hline$[2 \mathrm{~A}, 3 \mathrm{~B}, 3 \mathrm{~B}, 5 \mathrm{~A}]$ & 1 & 540 & {$[2 \mathrm{~A}, 3 \mathrm{~B}, 3 \mathrm{~B}, 4 \mathrm{~A}]$} & 1 & 576 \\
\hline$[2 \mathrm{~A}, 3 \mathrm{~B}, 3 \mathrm{~B}, 3 \mathrm{~B}]$ & 1 & 104 & {$[2 \mathrm{~A}, 5 \mathrm{~A}, 5 \mathrm{~A}, 6 \mathrm{~A}]$} & 3 & $\begin{array}{c}250,250,3 \\
30\end{array}$ \\
\hline$[2 \mathrm{~A}, 4 \mathrm{~A}, 5 \mathrm{~A}, 6 \mathrm{~A}]$ & 3 & $\begin{array}{c}340,365,36 \\
5\end{array}$ & {$[2 \mathrm{~A}, 4 \mathrm{~A}, 4 \mathrm{~A}, 6 \mathrm{~A}]$} & 3 & $\begin{array}{c}468,468,4 \\
24\end{array}$ \\
\hline$[2 \mathrm{~A}, 3 \mathrm{~B}, 5 \mathrm{~A}, 6 \mathrm{~A}]$ & 1 & 510 & {$[2 \mathrm{~A}, 3 \mathrm{~B}, 4 \mathrm{~A}, 6 \mathrm{~A}]$} & 1 & 600 \\
\hline$[2 \mathrm{~A}, 3 \mathrm{~B}, 3 \mathrm{~B}, 6 \mathrm{~A}]$ & 1 & 254 & {$[2 \mathrm{~A}, 5 \mathrm{~A}, 6 \mathrm{~A}, 6 \mathrm{~A}]$} & 3 & $95,95,160$ \\
\hline$[2 \mathrm{~A}, 4 \mathrm{~A}, 6 \mathrm{~A}, 6 \mathrm{~A}]$ & 3 & $\begin{array}{c}140,150,15 \\
0 \\
\end{array}$ & {$[2 \mathrm{~A}, 3 \mathrm{~B}, 6 \mathrm{~A}, 6 \mathrm{~A}]$} & 1 & 192 \\
\hline$[2 \mathrm{~A}, 6 \mathrm{~A}, 6 \mathrm{~A}, 6 \mathrm{~A}]$ & 3 & $30,30,80$ & {$[2 \mathrm{~A}, 3 \mathrm{~A}, 5 \mathrm{~A}, 7 \mathrm{~A}]$} & 1 & 175 \\
\hline$[2 \mathrm{~A}, 3 \mathrm{~A}, 5 \mathrm{~A}, 7 \mathrm{~B}]$ & 1 & 175 & {$[2 \mathrm{~A}, 3 \mathrm{~A}, 4 \mathrm{~A}, 7 \mathrm{~A}]$} & 1 & 266 \\
\hline$[2 \mathrm{~A}, 3 \mathrm{~A}, 4 \mathrm{~A}, 7 \mathrm{~B}]$ & 1 & 266 & {$[2 \mathrm{~A}, 3 \mathrm{~A}, 3 \mathrm{~B}, 7 \mathrm{~A}]$} & 1 & 119 \\
\hline$[2 \mathrm{~A}, 3 \mathrm{~A}, 3 \mathrm{~B}, 7 \mathrm{~B}]$ & 1 & 119 & {$[2 \mathrm{~A}, 3 \mathrm{~A}, 6 \mathrm{~A}, 7 \mathrm{~A}]$} & 1 & 105 \\
\hline$[2 \mathrm{~A}, 3 \mathrm{~A}, 6 \mathrm{~A}, 7 \mathrm{~B}]$ & 1 & 105 & {$[2 \mathrm{~A}, 3 \mathrm{~A}, 3 \mathrm{~A}, 5 \mathrm{~A}, 5 \mathrm{~A}]$} & 1 & 11350 \\
\hline$[2 \mathrm{~A}, 2 \mathrm{~A}, 5 \mathrm{~A}, 7 \mathrm{~A}]$ & 3 & $105,105,70$ & {$[2 \mathrm{~A}, 2 \mathrm{~A}, 5 \mathrm{~A}, 7 \mathrm{~B}]$} & 3 & $\begin{array}{c}105,105,7 \\
0\end{array}$ \\
\hline$[2 \mathrm{~A}, 2 \mathrm{~A}, 4 \mathrm{~A}, 7 \mathrm{~A}]$ & 3 & $\begin{array}{c}112,126,12 \\
6\end{array}$ & {$[2 \mathrm{~A}, 2 \mathrm{~A}, 4 \mathrm{~A}, 7 \mathrm{~B}]$} & 3 & $\begin{array}{c}112,126,1 \\
26\end{array}$ \\
\hline$[2 \mathrm{~A}, 2 \mathrm{~A}, 3 \mathrm{~A}, 7 \mathrm{~A}]$ & 1 & 126 & {$[2 \mathrm{~A}, 2 \mathrm{~A}, 3 \mathrm{~B}, 7 \mathrm{~A}]$} & 1 & 126 \\
\hline$[2 \mathrm{~A}, 2 \mathrm{~A}, 6 \mathrm{~A}, 7 \mathrm{~A}]$ & 3 & $56,56,28$ & {$[3 \mathrm{~A}, 3 \mathrm{~A}, 3 \mathrm{~A}, 5 \mathrm{~A}, 5 \mathrm{~A}]$} & 2 & 4050,1800 \\
\hline$[3 \mathrm{~A}, 3 \mathrm{~A}, 3 \mathrm{~A}, 3 \mathrm{~A}, 7 \mathrm{~B}]$ & 2 & 588,294 & {$[3 \mathrm{~A}, 3 \mathrm{~A}, 3 \mathrm{~A}, 4 \mathrm{~A}, 5 \mathrm{~A}]$} & 2 & 5400,5400 \\
\hline$[3 \mathrm{~A}, 3 \mathrm{~A}, 3 \mathrm{~A}, 4 \mathrm{~A}, 4 \mathrm{~A}]$ & 2 & 8064,8268 & {$[3 \mathrm{~A}, 3 \mathrm{~A}, 3 \mathrm{~A}, 3 \mathrm{~B}, 5 \mathrm{~A}]$} & 2 & 3150,1650 \\
\hline$[3 \mathrm{~A}, 3 \mathrm{~A}, 3 \mathrm{~A}, 3 \mathrm{~B}, 4 \mathrm{~A}]$ & 2 & 3804,3804 & {$[3 \mathrm{~A}, 3 \mathrm{~A}, 3 \mathrm{~A}, 4 \mathrm{~A}, 4 \mathrm{~A}]$} & 2 & 2160,1170 \\
\hline$[3 \mathrm{~A}, 3 \mathrm{~A}, 3 \mathrm{~A}, 5 \mathrm{~A}, 6 \mathrm{~A}]$ & 1 & 4950 & {$[3 \mathrm{~A}, 3 \mathrm{~A}, 3 \mathrm{~A}, 4 \mathrm{~A}, 6 \mathrm{~A}]$} & 1 & 6552 \\
\hline$[3 \mathrm{~A}, 3 \mathrm{~A}, 3 \mathrm{~A}, 3 \mathrm{~B}, 6 \mathrm{~A}]$ & 1 & 3120 & {$[3 \mathrm{~A}, 3 \mathrm{~A}, 3 \mathrm{~A}, 6 \mathrm{~A}, 6 \mathrm{~A}]$} & 1 & 2262 \\
\hline$[3 \mathrm{~A}, 3 \mathrm{~A}, 3 \mathrm{~A}, 3 \mathrm{~A}, 7 \mathrm{~A}]$ & 2 & 588,194 & {$[2 \mathrm{~A}, 3 \mathrm{~A}, 3 \mathrm{~A}, 6 \mathrm{~A}, 6 \mathrm{~A}]$} & 1 & 3552 \\
\hline$[2 \mathrm{~A}, 3 \mathrm{~A}, 3 \mathrm{~A}, 4 \mathrm{~A}, 5 \mathrm{~A}]$ & 1 & 18100 & {$[2 \mathrm{~A}, 3 \mathrm{~A}, 3 \mathrm{~A}, 4 \mathrm{~A}, 4 \mathrm{~A}]$} & 1 & 26676 \\
\hline$[2 \mathrm{~A}, 3 \mathrm{~A}, 3 \mathrm{~A}, 3 \mathrm{~B}, 5 \mathrm{~A}]$ & 1 & 8250 & {$[2 \mathrm{~A}, 3 \mathrm{~A}, 3 \mathrm{~A}, 3 \mathrm{~B}, 4 \mathrm{~A}]$} & 1 & 12060 \\
\hline$[2 \mathrm{~A}, 3 \mathrm{~A}, 3 \mathrm{~A}, 3 \mathrm{~B}, 3 \mathrm{~B}]$ & 1 & 5380 & {$[2 \mathrm{~A}, 3 \mathrm{~A}, 3 \mathrm{~A}, 5 \mathrm{~A}, 6 \mathrm{~A}]$} & 1 & 7350 \\
\hline
\end{tabular}




\begin{tabular}{|c|c|c|c|c|c|}
\hline$[2 \mathrm{~A}, 3 \mathrm{~A}, 3 \mathrm{~A}, 4 \mathrm{~A}, 6 \mathrm{~A}]$ & 1 & 10108 & {$[2 \mathrm{~A}, 3 \mathrm{~A}, 3 \mathrm{~A}, 3 \mathrm{~B}, 6 \mathrm{~A}]$} & 1 & 1698 \\
\hline$[2 \mathrm{~A}, 3 \mathrm{~A}, 3 \mathrm{~A}, 3 \mathrm{~A}, 7 \mathrm{~A}]$ & 1 & 1519 & {$[2 \mathrm{~A}, 3 \mathrm{~A}, 3 \mathrm{~A}, 3 \mathrm{~A}, 7 \mathrm{~B}]$} & 1 & 1519 \\
\hline$[2 \mathrm{~A}, 2 \mathrm{~A}, 3 \mathrm{~A}, 5 \mathrm{~A}, 5 \mathrm{~A}]$ & 1 & 19850 & {$[2 \mathrm{~A}, 2 \mathrm{~A}, 3 \mathrm{~A}, 4 \mathrm{~A}, 5 \mathrm{~A}]$} & 1 & 29900 \\
\hline$[2 \mathrm{~A}, 2 \mathrm{~A}, 3 \mathrm{~A}, 4 \mathrm{~A}, 4 \mathrm{~A}]$ & 1 & 42016 & {$[2 \mathrm{~A}, 2 \mathrm{~A}, 3 \mathrm{~A}, 3 \mathrm{~B}, 5 \mathrm{~A}]$} & 1 & 13650 \\
\hline$[2 \mathrm{~A}, 2 \mathrm{~A}, 3 \mathrm{~A}, 3 \mathrm{~B}, 4 \mathrm{~A}]$ & 1 & 18996 & {$[2 \mathrm{~A}, 2 \mathrm{~A}, 3 \mathrm{~A}, 3 \mathrm{~B}, 3 \mathrm{~B}]$} & 1 & 8290 \\
\hline$[2 \mathrm{~A}, 2 \mathrm{~A}, 3 \mathrm{~A}, 5 \mathrm{~A}, 6 \mathrm{~A}]$ & 1 & 11650 & {$[2 \mathrm{~A}, 2 \mathrm{~A}, 3 \mathrm{~A}, 4 \mathrm{~A}, 6 \mathrm{~A}]$} & 1 & 15508 \\
\hline$[2 \mathrm{~A}, 2 \mathrm{~A}, 3 \mathrm{~A}, 3 \mathrm{~B}, 6 \mathrm{~A}]$ & 1 & 7056 & {$[2 \mathrm{~A}, 2 \mathrm{~A}, 3 \mathrm{~A}, 6 \mathrm{~A}, 6 \mathrm{~A}]$} & 1 & 5350 \\
\hline$[2 \mathrm{~A}, 2 \mathrm{~A}, 3 \mathrm{~A}, 3 \mathrm{~A}, 7 \mathrm{~A}]$ & 1 & 2548 & {$[2 \mathrm{~A}, 2 \mathrm{~A}, 3 \mathrm{~A}, 3 \mathrm{~A}, 7 \mathrm{~B}]$} & 1 & 2548 \\
\hline$[2 \mathrm{~A}, 2 \mathrm{~A}, 2 \mathrm{~A}, 4 \mathrm{~A}, 5 \mathrm{~A}]$ & 3 & $\begin{array}{l}16200 \\
16200 \\
15600\end{array}$ & {$[2 \mathrm{~A}, 2 \mathrm{~A}, 2 \mathrm{~A}, 4 \mathrm{~A}, 4 \mathrm{~A}]$} & 3 & $\begin{array}{l}21816, \\
21816, \\
20736\end{array}$ \\
\hline$[2 \mathrm{~A}, 2 \mathrm{~A}, 2 \mathrm{~A}, 3 \mathrm{~B}, 5 \mathrm{~A}]$ & 1 & 21600 & {$[2 \mathrm{~A}, 2 \mathrm{~A}, 2 \mathrm{~A}, 3 \mathrm{~B}, 4 \mathrm{~A}]$} & 1 & 27648 \\
\hline$[2 \mathrm{~A}, 2 \mathrm{~A}, 2 \mathrm{~A}, 6 \mathrm{~A}, 6 \mathrm{~A}]$ & 3 & $\begin{array}{c}2364,2364 \\
3120\end{array}$ & {$[2 \mathrm{~A}, 2 \mathrm{~A}, 2 \mathrm{~A}, 5 \mathrm{~A}, 6 \mathrm{~A}]$} & 3 & $\begin{array}{c}6600,5700 \\
, 5700\end{array}$ \\
\hline$[2 \mathrm{~A}, 2 \mathrm{~A}, 2 \mathrm{~A}, 3 \mathrm{~B}, 6 \mathrm{~A}]$ & 1 & 10314 & {$[2 \mathrm{~A}, 2 \mathrm{~A}, 2 \mathrm{~A}, 3 \mathrm{~B}, 3 \mathrm{~B}]$} & 1 & 11088 \\
\hline$[2 \mathrm{~A}, 2 \mathrm{~A}, 2 \mathrm{~A}, 2 \mathrm{~A}, 7 \mathrm{~A}]$ & 3 & $\begin{array}{l}1568,2205 \\
2205\end{array}$ & {$[2 \mathrm{~A}, 2 \mathrm{~A}, 2 \mathrm{~A}, 2 \mathrm{~A}, 7 \mathrm{~B}]$} & 3 & $\begin{array}{c}1568,2205 \\
, 2205\end{array}$ \\
\hline$[2 \mathrm{~A}, 2 \mathrm{~A}, 2 \mathrm{~A}, 3 \mathrm{~A}, 7 \mathrm{~A}]$ & 1 & 4116 & {$[2 \mathrm{~A}, 2 \mathrm{~A}, 2 \mathrm{~A}, 3 \mathrm{~A}, 7 \mathrm{~B}]$} & 1 & 4116 \\
\hline$[2 \mathrm{~A}, 2 \mathrm{~A}, 2 \mathrm{~A}, 5 \mathrm{~A}, 5 \mathrm{~A}]$ & 3 & $\begin{array}{c}10800,1080 \\
0,12000\end{array}$ & $\begin{array}{c}{[2 \mathrm{~A}, 2 \mathrm{~A}, 2 \mathrm{~A}, 2 \mathrm{~A}, 3 \mathrm{~A}, 5} \\
\mathrm{A}]\end{array}$ & & 511,500 \\
\hline $\begin{array}{c}{[3 \mathrm{~A}, 3 \mathrm{~A}, 3 \mathrm{~A}, 3 \mathrm{~A}, 3 \mathrm{~A}, 5 \mathrm{~A}} \\
]\end{array}$ & 2 & $\begin{array}{c}37500,1750 \\
0\end{array}$ & $\begin{array}{c}{[3 \mathrm{~A}, 3 \mathrm{~A}, 3 \mathrm{~A}, 3 \mathrm{~A}, 3 \mathrm{~A}, 4} \\
\mathrm{A}]\end{array}$ & 2 & $\begin{array}{c}49280,492 \\
80 \\
\end{array}$ \\
\hline $\begin{array}{c}{[3 \mathrm{~A}, 3 \mathrm{~A}, 3 \mathrm{~A}, 3 \mathrm{~A}, 3 \mathrm{~A}, 3 \mathrm{~B}} \\
]\end{array}$ & 2 & $\begin{array}{c}14880,2880 \\
0 \\
\end{array}$ & $\begin{array}{c}{[3 \mathrm{~A}, 3 \mathrm{~A}, 3 \mathrm{~A}, 3 \mathrm{~A}, 3 \mathrm{~A}, 6} \\
\mathrm{A}]\end{array}$ & 1 & 44720 \\
\hline $\begin{array}{c}2 \mathrm{~A}, 3 \mathrm{~A}, 3 \mathrm{~A}, 3 \mathrm{~A}, 3 \mathrm{~A}, 6 \mathrm{~A} \\
]\end{array}$ & 1 & 68756 & $\begin{array}{c}{[2 \mathrm{~A}, 3 \mathrm{~A}, 3 \mathrm{~A}, 3 \mathrm{~A}, 3 \mathrm{~A}, 5} \\
\mathrm{A}]\end{array}$ & 1 & 105000 \\
\hline $\begin{array}{c}{[2 \mathrm{~A}, 3 \mathrm{~A}, 3 \mathrm{~A}, 3 \mathrm{~A}, 3 \mathrm{~A}, 4 \mathrm{~A}} \\
]\end{array}$ & 1 & 165696 & $\begin{array}{c}{[2 \mathrm{~A}, 3 \mathrm{~A}, 3 \mathrm{~A}, 3 \mathrm{~A}, 3 \mathrm{~A}, 3} \\
\mathrm{B}]\end{array}$ & 1 & 76128 \\
\hline $\begin{array}{c}{[2 \mathrm{~A}, 2 \mathrm{~A}, 3 \mathrm{~A}, 3 \mathrm{~A}, 3 \mathrm{~A}, 5 \mathrm{~A}} \\
]\end{array}$ & 1 & 184250 & $\begin{array}{c}{[2 \mathrm{~A}, 2 \mathrm{~A}, 3 \mathrm{~A}, 3 \mathrm{~A}, 3 \mathrm{~A}, 4} \\
\mathrm{A}]\end{array}$ & 1 & 276016 \\
\hline $\begin{array}{c}{[2 \mathrm{~A}, 2 \mathrm{~A}, 3 \mathrm{~A}, 3 \mathrm{~A}, 3 \mathrm{~A}, 3 \mathrm{~B}} \\
]\end{array}$ & 1 & 125418 & $\begin{array}{c}{[2 \mathrm{~A}, 2 \mathrm{~A}, 3 \mathrm{~A}, 3 \mathrm{~A}, 3 \mathrm{~A}, 6} \\
\mathrm{A}]\end{array}$ & 1 & 107454 \\
\hline $\begin{array}{c}{[2 \mathrm{~A}, 2 \mathrm{~A}, 2 \mathrm{~A}, 3 \mathrm{~A}, 3 \mathrm{~A}, 5 \mathrm{~A}} \\
]\end{array}$ & 1 & 311250 & $\begin{array}{c}{[2 \mathrm{~A}, 2 \mathrm{~A}, 2 \mathrm{~A}, 3 \mathrm{~A}, 3 \mathrm{~A}, 5} \\
\mathrm{A}]\end{array}$ & 1 & 446112 \\
\hline $\begin{array}{c}{[2 \mathrm{~A}, 2 \mathrm{~A}, 2 \mathrm{~A}, 3 \mathrm{~A}, 3 \mathrm{~A}, 3 \mathrm{~B}} \\
]\end{array}$ & 1 & 202968 & $\begin{array}{c}{[2 \mathrm{~A}, 2 \mathrm{~A}, 2 \mathrm{~A}, 3 \mathrm{~A}, 3 \mathrm{~A}, 6} \\
\mathrm{A}]\end{array}$ & 1 & 167916 \\
\hline $\begin{array}{c}{[2 \mathrm{~A}, 2 \mathrm{~A}, 2 \mathrm{~A}, 2 \mathrm{~A}, 3 \mathrm{~A}, 4 \mathrm{~A}} \\
]\end{array}$ & 1 & 710112 & $\begin{array}{c}{[2 \mathrm{~A}, 2 \mathrm{~A}, 2 \mathrm{~A}, 2 \mathrm{~A}, 3 \mathrm{~A}, 3} \\
\mathrm{B}]\end{array}$ & 1 & 318,438 \\
\hline $\begin{array}{c}{[2 \mathrm{~A}, 2 \mathrm{~A}, 2 \mathrm{~A}, 2 \mathrm{~A}, 2 \mathrm{~A}, 5 \mathrm{~A}} \\
]\end{array}$ & 1 & 511500 & $\begin{array}{c}{[2 \mathrm{~A}, 2 \mathrm{~A}, 2 \mathrm{~A}, 2 \mathrm{~A}, 2 \mathrm{~A}, 4} \\
\mathrm{A}]\end{array}$ & 1 & $1,093,120$ \\
\hline $\begin{array}{c}{[2 \mathrm{~A}, 2 \mathrm{~A}, 2 \mathrm{~A}, 2 \mathrm{~A}, 2 \mathrm{~A}, 3 \mathrm{~B}} \\
]\end{array}$ & 1 & 479,520 & $\begin{array}{c}{[2 \mathrm{~A}, 2 \mathrm{~A}, 2 \mathrm{~A}, 2 \mathrm{~A}, 2 \mathrm{~A}, 6} \\
\mathrm{A}]\end{array}$ & 1 & 392,040 \\
\hline $\begin{array}{c}{[2 \mathrm{~A}, 2 \mathrm{~A}, 2 \mathrm{~A}, 2 \mathrm{~A}, 3 \mathrm{~A}, 6 \mathrm{~A}} \\
]\end{array}$ & 1 & 258,864 & $\begin{array}{c}{[2 \mathrm{~A}, 2 \mathrm{~A}, 2 \mathrm{~A}, 2 \mathrm{~A}, 2 \mathrm{~A}, 2} \\
\mathrm{A}, 3 \mathrm{~A}]\end{array}$ & 1 & $\begin{array}{c}12,157,56 \\
0 \\
\end{array}$ \\
\hline $\begin{array}{c}{[2 \mathrm{~A}, 2 \mathrm{~A}, 3 \mathrm{~A}, 3 \mathrm{~A}, 3 \mathrm{~A}, 3 \mathrm{~A}} \\
, 3 \mathrm{~A}]\end{array}$ & 1 & 171960 & $\begin{array}{c}{[2 \mathrm{~A}, 2 \mathrm{~A}, 2 \mathrm{~A}, 3 \mathrm{~A}, 3 \mathrm{~A}, 3} \\
\mathrm{A}, 3 \mathrm{~A}]\end{array}$ & 1 & $2,904,744$ \\
\hline $\begin{array}{c}{[2 \mathrm{~A}, 2 \mathrm{~A}, 2 \mathrm{~A}, 2 \mathrm{~A}, 2 \mathrm{~A}, 3 \mathrm{~A}} \\
, 3 \mathrm{~A}]\end{array}$ & 1 & $7,690,320$ & $\begin{array}{c}{[2 \mathrm{~A}, 2 \mathrm{~A}, 2 \mathrm{~A}, 2 \mathrm{~A}, 3 \mathrm{~A}, 3} \\
\mathrm{A}, 3 \mathrm{~A}]\end{array}$ & 1 & 4765610 \\
\hline $\begin{array}{c}{[2 \mathrm{~A}, 2 \mathrm{~A}, 2 \mathrm{~A}, 2 \mathrm{~A}, 2 \mathrm{~A}, 2 \mathrm{~A}} \\
, 2 \mathrm{~A}]\end{array}$ & 1 & $18,828,480$ & $\begin{array}{c}{[2 \mathrm{~A}, 3 \mathrm{~A}, 3 \mathrm{~A}, 3 \mathrm{~A}, 3 \mathrm{~A}, 3} \\
\mathrm{A}, 3 \mathrm{~A}]\end{array}$ & 1 & 988960 \\
\hline $\begin{array}{c}{[3 \mathrm{~A}, 3 \mathrm{~A}, 3 \mathrm{~A}, 3 \mathrm{~A}, 3 \mathrm{~A}, 3 \mathrm{~A}} \\
, 3 \mathrm{~A}]\end{array}$ & 2 & $\begin{array}{l}353520, \\
169530 \\
\end{array}$ & & & \\
\hline
\end{tabular}


Table 6- Connected Components $\mathcal{H}_{\mathrm{r}, 1}^{\text {in }}(\mathrm{C})$ of $\mathrm{A}_{7}, \mathrm{n}=15$

\begin{tabular}{|c|c|c|c|c|c|c|}
\hline Group & $\begin{array}{c}\text { Ramification } \\
\text { type }\end{array}$ & $\begin{array}{c}\text { N. of } \\
\text { orbits }\end{array}$ & $\begin{array}{c}\text { Length of } \\
\text { orbits }\end{array}$ & $\begin{array}{c}\text { Ramification } \\
\text { type }\end{array}$ & $\begin{array}{c}\text { N. of } \\
\text { orbits }\end{array}$ & Length of orbits \\
\hline \multirow{6}{*}{$\mathrm{A}_{7}$} & {$[3 \mathrm{~A}, 3 \mathrm{~B}, 7 \mathrm{~A}]$} & 1 & 1 & {$[3 \mathrm{~A}, 3 \mathrm{~B}, 7 \mathrm{~A}]$} & 1 & 1 \\
\cline { 2 - 7 } & {$[3 \mathrm{~B}, 4 \mathrm{~A}, 6 \mathrm{~A}]$} & 6 & 1 & {$[3 \mathrm{~B}, 4 \mathrm{~A}, 6 \mathrm{~A}] 10$} & 10 & 1 \\
\cline { 2 - 7 } & {$[3 \mathrm{~B}, 4 \mathrm{~A}, 7 \mathrm{~A}]$} & 6 & 1 & {$[3 \mathrm{~B}, 4 \mathrm{~A}, 7 \mathrm{~B}]$} & 6 & 1 \\
\cline { 2 - 7 } & {$[4 \mathrm{~A}, 4 \mathrm{~A}, 4 \mathrm{~A}]$} & 24 & 1 & {$[2 \mathrm{~A}, 6 \mathrm{~A}, 7 \mathrm{~A}]$} & 2 & 1 \\
\cline { 2 - 7 } & {$[2 \mathrm{~A}, 5 \mathrm{~A}, 7 \mathrm{~A}]$} & 2 & 1 & {$[2 \mathrm{~A}, 7 \mathrm{~A}, 7 \mathrm{~A}]$} & 2 & 1 \\
\cline { 2 - 7 } & {$[2 \mathrm{~A}, 6 \mathrm{~A}, 7 \mathrm{~B}]$} & 2 & 1 & {$[2 \mathrm{~A}, 5 \mathrm{~A}, 7 \mathrm{~B}]$} & 2 & 1 \\
\cline { 2 - 7 } & {$[2 \mathrm{~A}, 7 \mathrm{~A}, 7 \mathrm{~B}]$} & 1 & 1 & {$[2 \mathrm{~A}, 7 \mathrm{~B}, 7 \mathrm{~B}]$} & 2 & 1 \\
\cline { 2 - 7 } & {$[2 \mathrm{~A}, 3 \mathrm{~B}, 3 \mathrm{~B}, 3 \mathrm{~B}]$} & 1 & 104 & {$[2 \mathrm{~A}, 2 \mathrm{~A}, 3 \mathrm{~B}, 4 \mathrm{~A}]$} & 1 & 192 \\
\cline { 2 - 7 } & {$[2 \mathrm{~A}, 2 \mathrm{~A}, 2 \mathrm{~A}, 7 \mathrm{~A}]$} & 2 & 21,21 & {$[2 \mathrm{~A}, 2 \mathrm{~A}, 2 \mathrm{~A}, 7 \mathrm{~B}]$} & 2 & 21,21 \\
\hline
\end{tabular}

Table 7- Connected Components $\mathcal{H}_{\mathrm{r}, 1}^{\mathrm{in}}(\mathrm{C})$ of $\mathrm{A}_{7} \mathrm{n}=21$

\begin{tabular}{|c|c|c|c|c|c|c|}
\hline $\begin{array}{c}\text { Grou } \\
\mathrm{p}\end{array}$ & $\begin{array}{c}\text { Ramification } \\
\text { type }\end{array}$ & $\begin{array}{c}\text { N. of } \\
\text { orbits }\end{array}$ & $\begin{array}{c}\text { Length of } \\
\text { orbits }\end{array}$ & $\begin{array}{c}\text { Ramification } \\
\text { type }\end{array}$ & $\begin{array}{c}\text { N. of } \\
\text { orbits }\end{array}$ & $\begin{array}{c}\text { Length of } \\
\text { orbits }\end{array}$ \\
\hline \multirow{7}{*}{$*$} & {$[3 \mathrm{~B}, 4 \mathrm{~A}, 4 \mathrm{~A}]$} & 8 & 1 & {$[4 \mathrm{~A}, 4 \mathrm{~A}, 4 \mathrm{~A}]$} & 24 & 1 \\
\cline { 2 - 7 } & {$[3 \mathrm{~B}, 3 \mathrm{~B}, 6 \mathrm{~A}]$} & 2 & 1 & {$[3 \mathrm{~B}, 4 \mathrm{~A}, 6 \mathrm{~A}]$} & 6 & 1 \\
\cline { 2 - 7 } & {$[4 \mathrm{~A}, 4 \mathrm{~A}, 6 \mathrm{~A}]$} & 12 & 1 & {$[3 \mathrm{~B}, 6 \mathrm{~A}, 6 \mathrm{~A}]$} & 2 & 1 \\
\cline { 2 - 7 } & {$[4 \mathrm{~A}, 6 \mathrm{~A}, 6 \mathrm{~A}]$} & 4 & 1 & {$[6 \mathrm{~A}, 6 \mathrm{~A}, 6 \mathrm{~A}]$} & 2 & 1 \\
\cline { 2 - 7 } & {$[3 \mathrm{~A}, 3 \mathrm{~B}, 7 \mathrm{~A}]$} & 1 & 1 & {$[3 \mathrm{~A}, 4 \mathrm{~A}, 7 \mathrm{~A}]$} & 2 & 1 \\
\cline { 2 - 7 } & {$[3 \mathrm{~A}, 3 \mathrm{~B}, 7 \mathrm{~B}]$} & 1 & 1 & {$[3 \mathrm{~A}, 4 \mathrm{~A}, 7 \mathrm{~B}]$} & 2 & 1 \\
\cline { 2 - 7 } & {$[3 \mathrm{~A}, 6 \mathrm{~A}, 7 \mathrm{~A}]$} & 1 & 1 & {$[3 \mathrm{~A}, 6 \mathrm{~A}, 7 \mathrm{~B}]$} & 1 & 1 \\
\cline { 2 - 7 } & {$[2 \mathrm{~A}, 5 \mathrm{~A}, 7 \mathrm{~A}]$} & 2 & 1 & {$[2 \mathrm{~A}, 5 \mathrm{~A}, 7 \mathrm{~B}]$} & 2 & 1 \\
\cline { 2 - 8 } & {$[2 \mathrm{~A}, 2 \mathrm{~A}, 2 \mathrm{~A}, 7 \mathrm{~A}]$} & 1 & 21 & {$[2 \mathrm{~A}, 2 \mathrm{~A}, 2 \mathrm{~A}, 7 \mathrm{~B}]$} & 1 & 21 \\
\hline
\end{tabular}

Table 8-Connected Components $\mathcal{H}_{\mathrm{r}, 1}^{\text {in }}(\mathrm{C})$ of $\mathrm{A}_{7}$, when $\mathrm{n}=35$

\begin{tabular}{|c|c|c|c|c|c|c|}
\hline $\begin{array}{c}\text { Grou } \\
\mathrm{p}\end{array}$ & $\begin{array}{c}\text { Ramification } \\
\text { type }\end{array}$ & $\begin{array}{c}\text { N. of } \\
\text { orbits }\end{array}$ & $\begin{array}{c}\text { Length of } \\
\text { orbits }\end{array}$ & $\begin{array}{c}\text { Ramification } \\
\text { type }\end{array}$ & $\begin{array}{c}\text { N. of } \\
\text { orbits }\end{array}$ & $\begin{array}{c}\text { Length of } \\
\text { orbits }\end{array}$ \\
\hline \multirow{2}{*}{ A7 } & {$[2 \mathrm{~A}, 6 \mathrm{~A}, 7 \mathrm{~A}]$} & 2 & 1 & {$[2 \mathrm{~A}, 6 \mathrm{~A}, 7 \mathrm{~B}]$} & 2 & 1 \\
\cline { 2 - 7 } & {$[3 \mathrm{~A}, 4 \mathrm{~A}, 4 \mathrm{~A}]$} & 8 & 1 & {$[3 \mathrm{~A}, 3 \mathrm{~A}, 6 \mathrm{~A}]$} & 2 & 1 \\
\hline
\end{tabular}

\section{References}

1. Aschbacher, M. 1990. On conjectures of guralnick and thompson. Journal of Algebra, 135(2):277343.

2. Aschbacher, M. and Scott, L. 1985. Maximal subgroups of finite groups. Journal of Algebra, 92(1):44-80.

3. Conway J.H., Curtis R. T., Norton S. P., Parker R. A. and Wilson R.A. 1985. Atlas of finite groups. Clarendon. Oxford.

4. Frohardt, D. and Magaard, K. 2001. Composition factors of monodromy groups. Annals of mathematics, Page 327-345.

5. Guralnick, R. and Thompson, J. 1990. Finite groups of genus zero. Journal of Algebra, 131(1): 303-341.

6. Khudhur, P. 2016. Sporadic Simple groups of low genus. PhD Thesis, University of Birmingham, UK.

7. MohammedSalih, H. 2015. Finite groups of small genus. $\mathrm{PhD}$ thesis, University of Birmingham, UK.

8. MohammedSalih, H. 2016. Determined Hurwitz components of $\mathrm{A}_{8}$. Journal of Zanko Sulaimani, 18-4-(Part-A).

9. Shih, T. 1991. A note on groups of genus zero. Communications in Algebra, 19(10): 2813-2826.

10.Volkein He.1996. Groups as Galois groups: an introduction, Volume 53. Cambridge University press. 